p-ISSN 1693-1246

e-ISSN 2355-3812

January 2019

\title{
Determination of The Rotational Friction Coefficients of Solid Cylinder with Various Inclined Plane Angle
}

\author{
T. Firdaus ${ }^{1 *}$, M. Toifur ${ }^{2}$, Y. Pramudya² \\ ${ }^{1}$ Program Studi Pendidikan Fisika, Sekolah Tinggi Keguruan dan Ilmu Pendidikan Nurul Huda, Indonesia \\ ${ }^{2}$ Pascasarjana Pendidikan Fisika, Universitas Ahmad Dahlan, Indonesia
}

Submitted: 18 July 2018. Revised: 29 December 2018. Accepted: 1 January 2019

\begin{abstract}
The layer texture differences of an object have an influence on the friction force caused by both planes. This research aims to determine the static and kinetic friction coefficient on several solid cylinder materials. The benefits of this research can be used to develop experimental learning activities on friction coefficient. This research used experimental method. The research was carried out by rolling samples at various inclined plane angles and measuring the traveled distance traveled in one rotation (D). The results showed that the static and kinetic friction coefficients between aluminum cylinder and glass were 0.146 and 0.097 , iron cylinder and glass were 0.136 and 0.096 , glass cylinder and brass were 0.132 and 0.094 , nylon cylinder and glass were 0.101 and 0.090 , and stainsless cylinder and glass were 0.122 and 0.094 , respectively.
\end{abstract}

\section{ABSTRAK}

Perbedaan tekstur lapisan sebuah benda mempunyai pengaruh pada gaya gesek yang ditimbulkan oleh kedua bidang. Penelitian ini bertujuan untuk menentukan nilai koefisien gesek statis dan koefisien gesek kinetik pada beberapa bahan silinder pejal. Manfaat yang dapat diambil dari hasil penelitian ini adalah dapat digunakan sebagai mengembangkan kegiatan pembelajaran praktikum koefisien gesekan benda. Penelitian ini menggunakan metode eksperimen. Penelitian dilaksanakan dengan menggelindingkan sampel pada berbagai sudut kemiringan dan mengukur jarak tempuh untuk satu kali putaran (D). Hasil penelitian menunjukkan bahwa nilai koefisien gesek statis dan koefisien gesek kinetik secara berurutan untuk silinder aluminium dengan kaca sebesar 0,146 dan 0,097, untuk silinder besi dengan kaca sebesar 0,136 dan 0,096, untuk silinder kuningan dengan kaca 0,132 dan 0,094, untuk silinder nylon dengan kaca sebesar 0,101 dan 0,090, dan untuk stainsless dengan kaca sebesar 0,122 dan 0,094.

Keywords: Solid Cylinder; Static and Kinetic Friction Coefficient

\section{INTRODUCTION}

A person always has activities with rough and smooth surface of objects. Heck \& Van Buuren (2017) said that magnitude of frictional force is comparable with the rougness of object surface, meaning that the difference in coating texture affects to the friction that arises on the object being touched. For examples, the touch of footwear on floor, motorcycle wheels on asphalt, table legs on floor, and so on. The touch of the motorbike on the asphalt will be different from the touch between the table legs and the floor. The difference is in the adhesion

${ }^{*}$ Correspondence Address:

JI Kota Baru, Sukaraja, Buay Madang OKU Timur, 32161

E-mail: thohaf@stkipnurulhuda.ac.id that is generated from both surface objects.

Friction is a type of concept in physics that is easy to apply in dailylife (Balta, 2016). For example, on the touch of footwear that someone wears on inclined floor surface. The person will not slip if the force $\mathbf{F}$ with down-direction on the blade is smaller than the opposite force. The force which keeps the balance and static footwear works in opposite direction of the force $\mathbf{F}$, the balancing force is called static friction force $\mathbf{f}_{\mathrm{s}}$. On the surface of a rough object, at the end of the contact surface will cause friction which limits the movement of objects on the surface in opposite. If the footwear on the right sloping floor surface will slip, the score of $f_{\mathrm{s}}$ maximum value $f_{\text {smaks }}$. So that when the footwear moves slipping, the friction force will return to less than $f_{\text {smaks }}$. The friction when 
the object is moving called kinetic friction $\mathbf{f}_{\mathbf{k}}$ (Serway \& Jewett, 2009).

The origin of static friction is similar to that arising when a rectangular beam is placed on a slope. At a small slope angle, static friction prevents the beam from slipping down (Cross, 2018). However, the friction signal does not only occur in longitudinal plates as beam, which all surfaces touch with the floor. However, it also occurs in objects in the form of cylinder. In cylindrical objects, the surface contacts with the floor is only small part of cylinder surface, which is a straight line. The rolling cylinder, do not slip when rolling perfectly, which if the distance traveled in one round is the same as the circumference of the cylinder circle. Whereas if the cylindrical distance that rolls one time is more than the circumference of the cylinder circle, then there is slippage. The factors affects the cylinder slip or not depends on the slope angle (Cross, 2015) and the surface texture of the object (Serway \& Jewett, 2009).

In addition to knowing the comparison of the surface types of objects, this experiment can also determine the critical angle, static and kinetic friction coefficient. The critical angle is the boundaries angle between rolling without slippage and with slippage (Physics, nd). So this affects the static coefficient of friction value. If the object has a small slope critical angle, it means the object tends to be smooth and has a small static friction coefficient value. If the object has a large critical angle, then the object tends to be more rough and has a static friction coefficient that tends to be large.

Figure 1 is an experimental Figure and style formed as solid cylinder will or crossing incline.

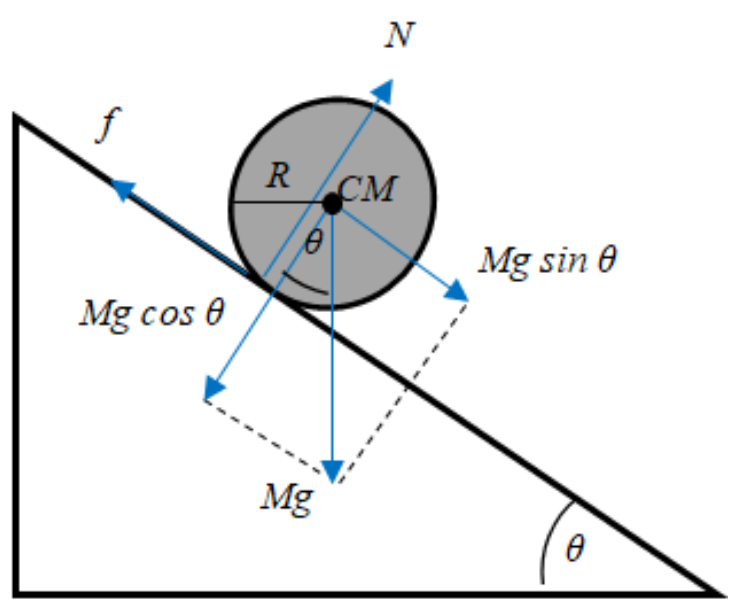

Figure 1. Solid cylinder above a sloping surface raises several styles

$$
I_{C M}=\frac{-M R^{-}}{2}
$$

If the solid cylinder rolls without slippage, then

$\alpha=\frac{a_{C M}}{R}$

by substituting the equation (4) and equation

(5) in equation (3), then obtained

$$
a_{\mathscr{M}}=\frac{2 f}{M}
$$

If it returns to equation (1), the forces works on translational motion can be written as

$$
M g \sin \theta-f=M a_{C M}
$$

So that equation (6) can be substituted in equation (7), and the friction force is equal to

$f=\frac{1}{3} M g \sin \theta$

Acceleration at the center of mass when the cylinder rolls without slippage can be searched by substituting equation (8) in equation (6) and obtaining

$a_{C M}=\frac{2}{3} g \sin \theta$

In the condition of equation (8), friction force $f$ is always smaller or equal to the maximum value. To get the maximum static friction coefficient, the equation $f_{\text {smax }}=\mu_{s} N p$ there is a sloping field, applies

$$
f_{s}=\mu_{s} M g \cos \theta
$$

Thus, equation (8) and equation (10) become $\frac{1}{3} M g \sin \theta=\mu_{s} M g \cos \theta$

or

$\tan \theta=3 \mu_{s}$

For the condition of the object rolling without slippage, the angle applies $\tan \theta<3 \mu_{s}$, whereas if $\tan \theta>3 \mu_{s}$ then the cylinder rolls slippage. Therefore, there is a boundary angle between rolling without slippage and with slippage. The boundary angle is called the critical 
angle $\theta_{c}$. Critical angle can be written as a function of $\mu_{s}$.

$\mu_{s}=\frac{1}{3} \tan \theta_{c}$

If the angle $\theta$ in Figure 1 greater than $\theta_{c}$ the cylinder rolls with slippage along the inclined plane so that the traces of cylindrical dots obtained have a distance that is not the same as Figure 2.

The force works on the slipping cylinder is kinetic friction so that

$$
f_{k}=\mu_{k} M g \cos \theta
$$

So that from equation (1) can be searched its acceleration by substituting it to equation (14), then becomes

$$
\begin{aligned}
& M g \sin \theta-\mu_{k} M g \cos \theta=M a_{C M} \\
& g \sin \theta-\mu_{k} g \cos \theta=a_{C M} \\
& a_{C M}=g\left(\sin \theta-\mu_{k} \cos \theta\right)
\end{aligned}
$$

And from equation (2), angular acceleration is obtained by substituting equation (4) and equation (14) so that it becomes

$\alpha=\frac{2 \mu_{k} g \cos \theta}{R}$

One rotation of the cylinder marked with the distance between two adjacent points as in the Figure 2. Distance references used in this study is the first distance in one rotation, so for rotation without any slippage distance between two points equal to the circumference of a circle $2 \pi R$.

Since cylinder starting from rest in position $X=0$, position $C M$ changes with time $t$, so that it follows the equation of Regular Changed Motion:

$X_{L}=\frac{1}{2} a_{\mathbb{M}} t^{2}=\frac{1}{2} g\left(\sin \theta-\mu_{k} \cos \theta\right) t^{2}$

Meanwhile the cylinder rotates at an angle:

$\Omega=\frac{1}{2} \alpha t^{2}=\frac{\mu_{k} g \cos \theta}{R} t^{2}$
Because when the cylinder rolls there is slippage, the length of $X_{L}$ is not the same as the length

$$
\begin{aligned}
& X_{\Omega}=\Omega R \\
& \text { or } \\
& X_{\Omega}=\mu_{k} g \cos \theta t^{2}
\end{aligned}
$$

and there are transfers about $\Delta X$, whose value is:

$$
\begin{aligned}
& \Delta X=X_{L}-X_{\Omega} \\
& \Delta X=\frac{1}{2} g\left(\sin \theta-3 \mu_{k} \cos \theta\right) t^{2}
\end{aligned}
$$

The time for $N$ rotation can be determined using equation (20) where if $X_{\Omega}$ is the first round or $2 \pi R$, then:

$$
2 \pi R N=\mu_{k} g \cos \theta t_{N}^{2}
$$

$t_{N}=\left[\frac{2 N \pi R}{\mu_{k} g \cos \theta}\right]^{\frac{1}{2}}$

$\Delta X_{N}$ for each $N$ all rotations that change with time can be determined by substituting equation (23) in equation (21) so that:

$\Delta X_{N}=N \pi R\left(\frac{\tan \theta}{\mu_{k}}-3\right)$

When viewed from Figure 2, for the value of distance of each point then apply:

$D=X_{\Omega}+\Delta X_{N}$,

So that the slipping distance in the first rotation $(N=1)$ will apply the equation:

$D=2 \pi R+\pi R\left(\frac{\tan \theta}{\mu_{k}}-3\right)$

Value $D$ is different from the value of $X_{L}$, because $D$ is the distance for each $N$ round times. As the angle increases, the cylinder will also rotate with slippage. This motion is illustrated in Figure 3. 


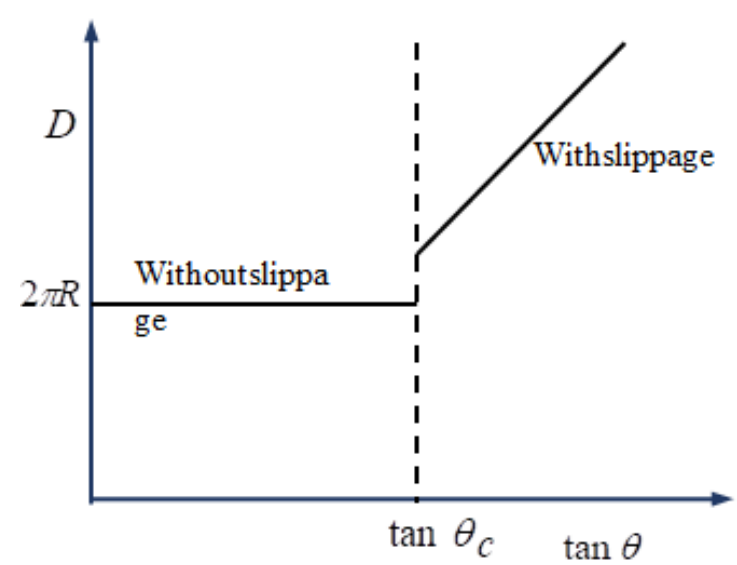

Figure 3. Relationship between slope angle and distance.

Figure 3 shows motion without slippage when the difference in distance is constant $(2 \pi R)$, while slippage is indicated by a linear line. Using linear lines with the form of equations $y=a+b$, then equation (26) can be simplified from its linear line to:

$$
D=\frac{\pi R \tan \theta}{\mu_{k}}-\pi R
$$

With $D$ is the distance between the first two round points, $\mathrm{R}$ is the cylinder radius, $\tan \theta$ is the slope angle, and $\mu_{k}$ is coefficient of static friction.

Follow linear equation, if $D$ as $y$ and tan

$\theta$ as a function of $\mathrm{x}$, then the value of a from gradient linear equation is

$$
\begin{aligned}
& a=\frac{\pi R}{\mu_{k}}, \text { or } \\
& \mu_{k}=\frac{\pi R}{a}
\end{aligned}
$$

Aims of this research is determine coefficient of solid cylinder friction on various materials, including aluminum, stainless steel, brass, iron, and nylon rolled above glass.

\section{METHOD}

Procedure of research conducted following flowchart as in the view Figure 4. This research used five solid cylinder materials, including aluminum, brass, stainless, iron, and Nylon. All of them were $\pm 5 \mathrm{~cm}$ long and \pm 4.5 $\mathrm{cm}$ in diameter. Then the glass material as trajectory of cylinder that rolled. In addition there were some ingredients that need cleaning, so that the nature of pure material did not mix with rust and others.

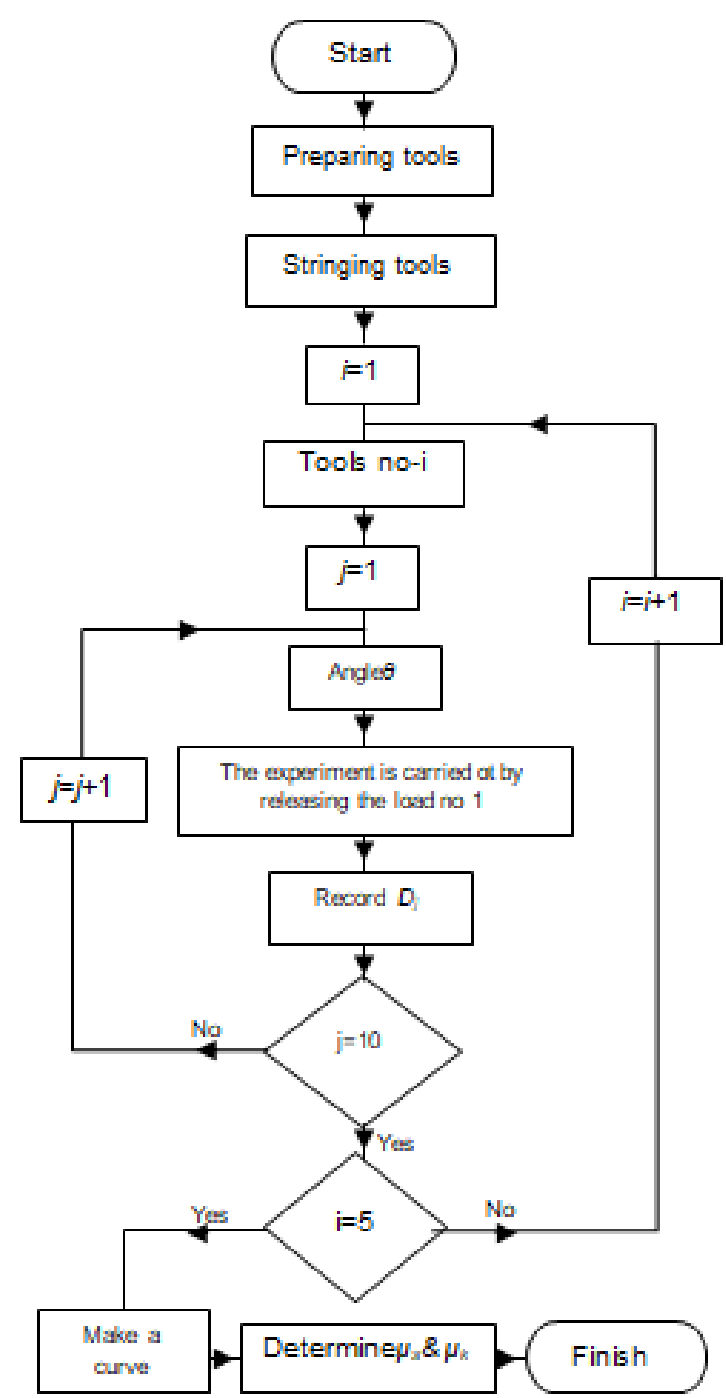

Figure 4. FlowChart data retrieval procedure

The tools prepared in this study was glass board, as rolling cylindrical track material with size $\pm(75 \times 10) \mathrm{cm}^{2}$. Besides that there were glass board and tools board, made from wood for strengthen stand tools so that it did not collapsed. A protractor as angle measuring instrument is also needed for make it easier vary angle in this research. There were pendulum and thin rope, as a tool displaying angle, showed angle instructions more accurate. Pendulum made from lead because more simple and efficient. Then there were one brush, and ink as cylindrical rolling trace marker. A measuring tape used for make it easier to measure imprinted ink distance. And the last was duck 
tape as brush adhesive so that it did not slip when cylinder was rolled.

The procedure steps in data retrieval were; the first, prepared tools and materials then stringing tool experiment as in Figure 5 .

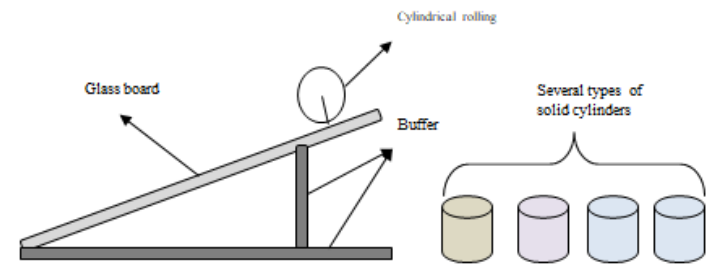

Figure 5. Tools design for determination swipe coefficient on cylinder solid material

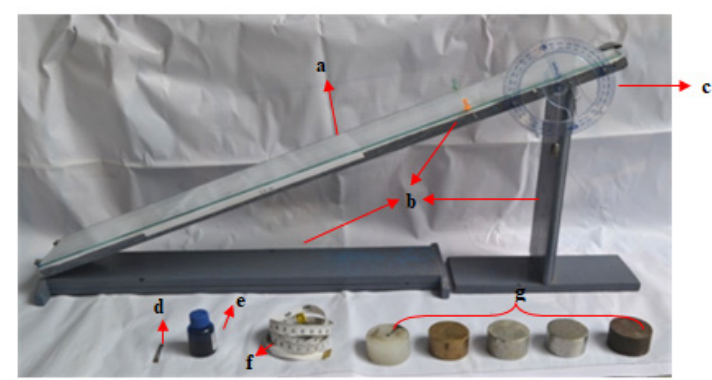

Figure 6. Tools design for determination swipe coefficient on cylinder solid material

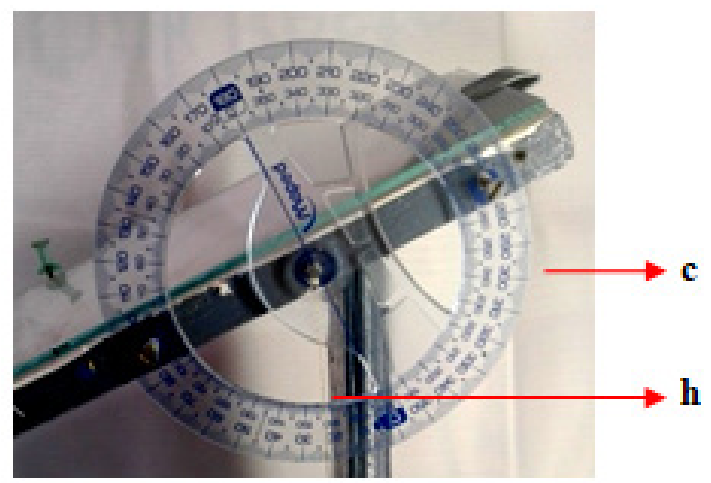

Figure 7. Details of experiment tool on the protractor. Captions 6 and 7: (a). Glass, (b). Wooden board, (c). Protractor, (d). Brush, (e). Ink, (f). Measuring tape, (g). Solid cylinder material, (h). Rope, (i). Ballast pendulum.

Attached brush which has been given ink on the tip of cylinder with duct tape. Brush position placed at the end of cylinder given a little arises, which its functions for clarify trace line when cylinder rolled, it can be seen in Figure 8. After that, set the track slope.

Started the experiment, released cylinder Started the experiment, released cylinder which has been placed above slope. Recorded the result of first round distance on the cylinder which has been marked by a brush rolled above the glass. Repeated this trial with various angle variant that has been determined. Obtained the data, made it in form of chart then analyzed it.

From the data already obtained, then made chart correlation between angle tan $\theta$ with the distance between first two round points $D$. The graph hypothesis results would be obtained as the Figure 3. On that Figure, the chart correlation between cylinder round distance with tan slope angle got pattern chart without slippage in form of horizontal lines, and chart pattern with slippage in form of linear lines (Ludwigsen \& Svinarich, 2009).

Data were shared to be two part, that were straight and linear lines. The same data was fitting and forming line straight, then the changed data was fitting and forming linear line. Analyzed linear formed data using linear regression without weighted. Linear equation is used for determine critical angle value, that was intersection angle between line straight with linear line. The critical angle score is used to find coefficient of swipe static followed equation (13). While gradient score is used to find coefficient of kinetic friction score followed equation (28).

\section{RESULTS AND DISCUSSION}

In Figure 8, a cylinder rolls on the glass and the path of rolling can be observed from the printed ink due to a brush attached on to the side of the cylinder.

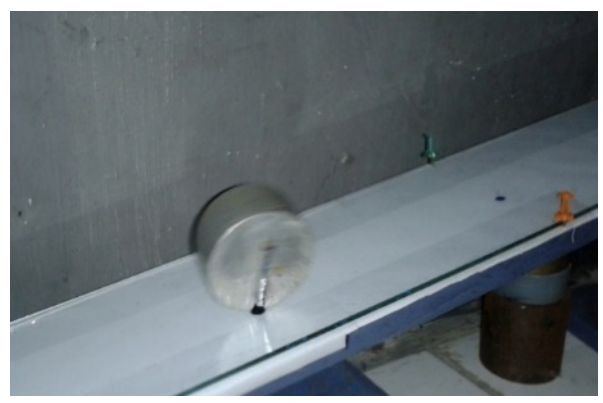

Figure 8. Solid cylinder rolls on a glass surface.

The following were the results of the experiment of each sample and the analysis of the obtained data 


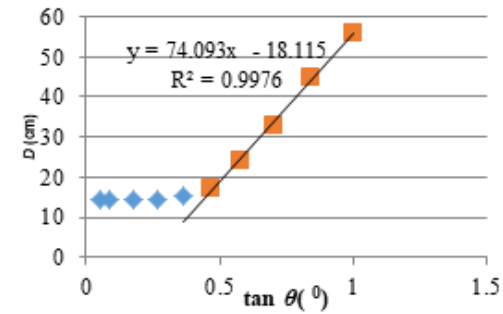

Figure 9. Correlation between $\tan \theta$ and distance of first two-round points $(D)$ of aluminum cylinder.

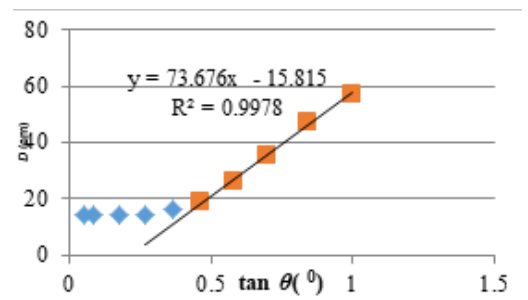

Figure 10. Correlation between $\tan \theta$ and distance of first two-round points $(D)$ of iron cylinder.

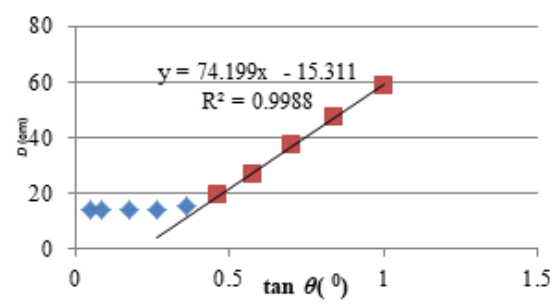

Figure 11. Correlation between $\tan \theta$ and distance of first two-round points $(D)$ of brass cylinder.

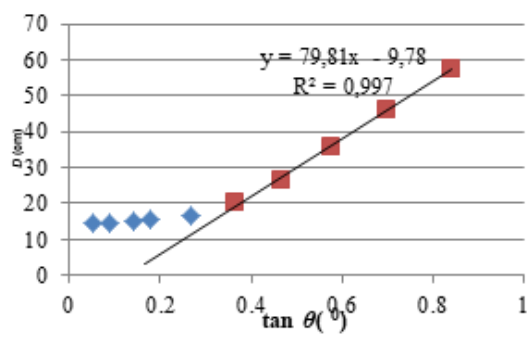

Figure 12. Correlation between $\tan \theta$ and distance of first two-round points $(D)$ of nylon cylinder.

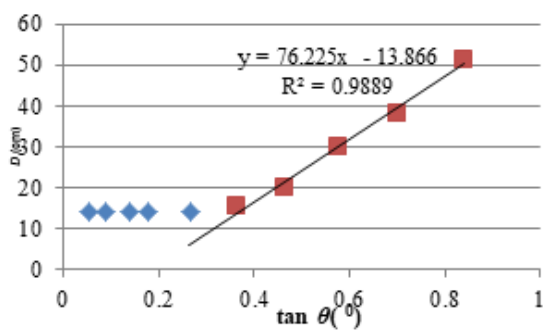

Figure 13. Correlation between $\tan \theta$ and distance of first two-round points $(D)$ of stainless cylinder.

The analysis used linear regression without weighing, because to sketch one graphic, the experiment has done by many different angles, so the obtained data was valid, Table 1.

The results had some diferences to other materials observed from other studies, Table 2. Besides, this research modifies the process of data collection, namely by combining horizontal

Table 1. The static and kinetic friction coefficients.

\begin{tabular}{lll}
\hline Material sample & & \\
\hline Aluminum with glass & $0.146 \pm 0.003$ & $0.097 \pm 0.003$ \\
Iron with glass & $0.136 \pm 0.003$ & $0.096 \pm 0.003$ \\
Brass with glass & $0.132 \pm 0.003$ & $0.094 \pm 0.011$ \\
Nylon with glass & $0.101 \pm 0.003$ & $0.090 \pm 0.030$ \\
Stainless with glass & $0.122 \pm 0.003$ & $0.094 \pm 0.031$ \\
\hline
\end{tabular}

Table 2. The coefficients of static and kinetic friction on materials by various sources.

\begin{tabular}{llll}
\hline Material sample & & \multicolumn{1}{c}{ Source } \\
\hline PVC with wood board & $0.2203 \pm 0$. & $0.1594 \pm$ & Yan, Xia, Lan, \& Xiao, (2018) \\
$\begin{array}{l}\text { Plexiglass with wood } \\
\text { board }\end{array}$ & $0.2223 \pm$ & 0.0030 & \\
$\begin{array}{l}\text { Plexiglass with Plastic } \\
\text { board }\end{array}$ & 0.0090 & 0.0044 & Yan, Xia, Lan, \& Xiao, (2018) \\
Wood with steel & 0.0097 & $0.2130 \pm$ & Yan, Xia, Lan, \& Xiao, (2018) \\
Wood and glass & 0.131 & - & $\begin{array}{l}\text { Phommarach, Wattanakasiwich, \& } \\
\text { Johnston, (2012) }\end{array}$ \\
\hline & $0.24 \pm 0.08$ & $0.19 \pm 0.02$ & $\begin{array}{l}\text { (Tunyagi, Kandrai, Fülöp, Kapusi, \& } \\
\text { Simon, 2018) }\end{array}$ \\
\hline
\end{tabular}


line equations and linear equations (Ludwigsen \& Svinarich, 2009), so it gave one right point to observe. Table 2 are compilation of other studies with different samples.

Comparing from the previous studies conducted by Yan, Xia, Lan, \& Xiao, (2018) by using hollow solid cylinder material which is rolled on a sloping board. The experimental results found that the friction force deviates from the theoretical results when the position is close to the critical angle. Obtained data from this research including PVC with wood board for $\mu \mathrm{s}$ $=0.2203 \pm 0.0092$ and $\mu_{k}=0.1594 \pm 0.0030$, plexyglass with wood board $\mu_{\mathrm{s}}=0.2223 \pm$ 0.0090 and $\mu_{\mathrm{k}}=0.1770 \pm 0.0044$, and plexyglass with plastic board $\mu_{\mathrm{s}}=0.2414 \pm 0.0097$ and $\mu_{\mathrm{k}}=0.2130 \pm 0.0031$.

Subsequent research was carried out by Phommarach, Wattanakasiwich, \& Johnston, (2012), on wood and steel surfaces was found that static friction coefficient was equal to 0.131 and the critical angle for solid cylinder was at $21.45^{\circ}$. Agus \& Syafaat (2012) revealed that the greatest friction force was obtained in the condition without lubricants. In conditions without lubrication, the more rough the surface, the greater the friction force.

From the various kinds of research, several researchers took some materials only, whereas other materials have not reviewed yet. Other research (Agus \& Syafaat, 2012; Hartati, 2010) did experiments by using varied materials, however the whole experiment has done by observing a side touched the floor (for example, in a bar shaped materials) .

Jati \& Murdaka (2018) did experiment with moved cylinder of metal object on a table surface layered with glass by pulling a rope attached on the load. However in their experiment, metal position stood up so that large surface touched the floor. Whereas in this research, the measurement of friction coefficient on solid cylinder material was in horizontal position, so it minimalized surface touching the floor.

The friction coefficient were different due to the different types of cylindrical sample layer types. The correlation graphics between one cylinder rotation and $\tan \theta$ gave different slope gradient, that affected to the results of friction coefficient. The steeper the gradient produced, the greater the gradient, so that the kinetic friction coefficient was smaller, because the gradient was inversely proportional to the kinetic friction coefficient that agreed to the equation (28). The above experiments had average er- ror rate 0.003

While the static friction coefficient depended on the produced critical angle, namely the intersection of linear line gradients with a straight line. Cylinder layer with rough texture will have a greater critical angle than the smooth one. So it can be concluded that the types of cylinders which have rough texture to smooth layers respectively are aluminum, iron, brass, stainless, and nylon.

Optimizing the research, researchers should repeat the experiment many times due to several factors including the texture of glass that tends to be slippery compared to wood, concrete, or others. In order to avoid external factors that affect errors in experiments, e.g. when releasing a cylinder at a large angle height, experiment should do in careful handling, because a hand pushing may be a factor of un-control rolling cylinder.

\section{CONCLUSION}

Based on the results of the study, the static and kinetic friction coefficient can be measured between two surfaces of solid cylinders from aluminum, iron, brass, nylon, and stainless, on a glass track. This study has been tested and the results have an accuracy of $0.3 \%$ to $3 \%$.

This research can be re-developed by adding object sample variables or by changing the shape of object samples such as sphere. In addition to obtain real benefits, further research may use material samples: wheeled vehicle tires and asphalt.

\section{REFERENCE}

Agus, B., \& Syafaat, I. (2012). Karakterisasi Koefisien Gesek Permukaan Baja St 37 pada Bidang Datar Terhadap Viskositas Pelumas. Momentum, 8(2), 11-18.

Balta, N. (2016). Oscillations of a Meterstick on Two Rotating Shafts. The Physics Teacher, 54(3), 145-145. https://doi.org/10.1119/1.4942132

Cross, R. (2015). Rolling to a stop down an inclined plane. European Journal of Physics, 36(6).

Cross, R. (2018). Static friction on a ball rolling down an incline. Physics Education, 53(6).

Hartati, B. (2010). Pengembangan alat peraga gaya gesek untuk meningkatkan keterampilan berpikir kritis siswa sma. Jurnal Pendidikan Fisika Indonesia, 6(2), 128-132.

Heck, A., \& Van Buuren, O. (2017). Ramp it up and down. Physics Education, 52(1), 1-11.

Jati, B. M. E., \& Murdaka, H. R. (2018). Formulasi Koefisien Gesekan Kinetis pada Gaya Ge- 
sekan antara Benda dengan Lanta. Jurnal Mipa, 35(0215), 157-164.

Ludwigsen, D., \& Svinarich, K. (2009). Choose Wisely: Static or Kinetic Friction-The Power of Dimensionless Plots. The Physics Teacher, 47(3), 158-161.

Phommarach, S., Wattanakasiwich, P., \& Johnston, I. (2012). Video analysis of rolling cylinders. Physics Education, 47(2), 189-196.

Physics, B. U. (n.d.). 5-1 Kinetic Friction. In Chapter 5 - Applications of Newton's Laws (pp. 1-6).
Serway, R. A., \& Jewett, J. W. (2009). Fisika untuk sains dan teknik. Jakarta: Salemba Teknika.

Tunyagi, A., Kandrai, K., Fülöp, Z., Kapusi, Z., \& Simon, A. (2018). Friction coefficient determination by electrical resistance measurements. Physics Education, 53(3).

Yan, Z., Xia, H., Lan, Y., \& Xiao, J. (2018). Variation of the Friction Coefficient for a Cylinder Rolling down an Inclined Board. Physics Education, 53(1). 